\title{
APPLICATION OF COMPUTED TOMOGRAPHY IN COMPARISON WITH THE STANDARDIZED METHODS FOR DETERMINING THE PERMEABILITY OF CEMENT-COMPOSITE STRUCTURES
}

\author{
UPORABA RAČUNALNIŠKE TOMOGRAFIJE V PRIMERJAVI S \\ STANDARDIZIRANIMI METODAMI DOLOČANJA PREPUSTNOSTI \\ CEMENTNIH KOMPOZITNIH STRUKTUR
}

\author{
Tereza Komárková, Monika Králíková, Pavel Kovács, Dalibor Kocáb, \\ Tomáš Stavař \\ Brno University of Technology, Faculty of Civil Engineering, Veveří 331/95, 60200 Brno, Czech Republic \\ kralikovam@fce.vutbr.cz \\ Prejem rokopisa - received: 2014-08-14; sprejem za objavo - accepted for publication: 2014-09-30
}

doi:10.17222/mit.2014.194

\begin{abstract}
The paper deals with various testing methods for evaluating the surface layer (the concrete cover) of concrete on which the durability of the whole composite depends. The key parameters for determining concrete permeability are the pore volume, size and distribution in the material and the relating water and air permeability. The aim of the experiment was to compare the results of the permeability measurement of the surface layer of concrete using standardized methods (depth of penetration of water under pressure, ISAT, GWT, TPT) with the outputs provided with computed tomography (CT). Based on the measurement results, CT appears to be an inappropriate method for evaluating the permeability of the surface layer of concrete. Circumstances that may limit the test method are described in detail in the article.

Keywords: concrete, durability, permeability, computed tomography
\end{abstract}

Članek obravnava različne preizkusne metode za oceno površinske plasti betona, od katere je odvisna vzdržljivost kompozita. Ključni parameter za določanje prepustnosti betona je ugotavljanje volumna, velikosti in razporeditve por v materialu ter z njimi povezana prepustnost vode in zraka. Namen eksperimenta je bil primerjati meritve prepustnosti površinskega sloja betona s standardiziranimi metodami (globina penetracije vode pod tlakom, ISAT, GWT, TPT) z rezultati, dobljenimi z računalniško tomografijo (CT). Na osnovi rezultatov meritev je videti, da CT ni primerna metoda za oceno prepustnosti površinskega sloja betona. V članku so podrobno opisane okoliščine, ki lahko omejujejo metodo preizkusa.

Ključne besede: beton, vzdržljivost, prepustnost, računalniška tomografija

\section{INTRODUCTION}

Concrete is used as a composite building material in most branches of the building industry and concrete structures are found in a number of places worldwide while the issue of their deterioration has been an increasing problem. This is illustrated by the fact that approximately $50 \%$ of the expenses in the construction in Europe relates to repairs, maintenance and rehabilitation of concrete structures. ${ }^{1}$ Very important criteria for a construction design are the intended purpose, the location and, especially, the environmental conditions which may affect it.

Durability is defined as resistance to weather, chemical attack, abrasion and other degradation processes. ${ }^{2}$ With a correct construction design, its execution and subsequent treatment, the durability of the material can be much longer than the expected life cycle. The requirement for durability of building materials (including concrete) is now included in the CPR (Construction Products Regulation). ${ }^{3}$

Concrete durability can also be visualised according to Sommerville (Figure 1) ${ }^{4}$. Curve 1 in Figure 1 shows the minimum reduction in quality over time. The most frequently occurring progression of concrete durability is shown by curve 2 where there is an apparent deterioration over time but, thanks to repairs and maintenance, its quality can be remedied. The third curve characterises the concretes that are rarely used for building and it is clear that over time there can be a significant loss in their durability. In order to prevent a large durability reduction over time, it would be advisable to perform continuous monitoring of a construction, especially in terms of its maintenance and in some cases also during the construction. Unfortunately, this is not always possible and, therefore, a random quality assessment of concrete constructions is the only performable method today. ${ }^{1}$

The most important aspects influencing concrete deterioration are, for instance, seasonal temperature variations, cyclic freezing and thawing, precipitation, changes in relative humidity and pollutant concentrations in the atmosphere or in water. Generally speaking, contact with water is the main cause of concrete degradation. Water permeation into concrete is the key parameter influencing the degree of damage to concrete and it can be said, therefore, that in general terms the permeability 


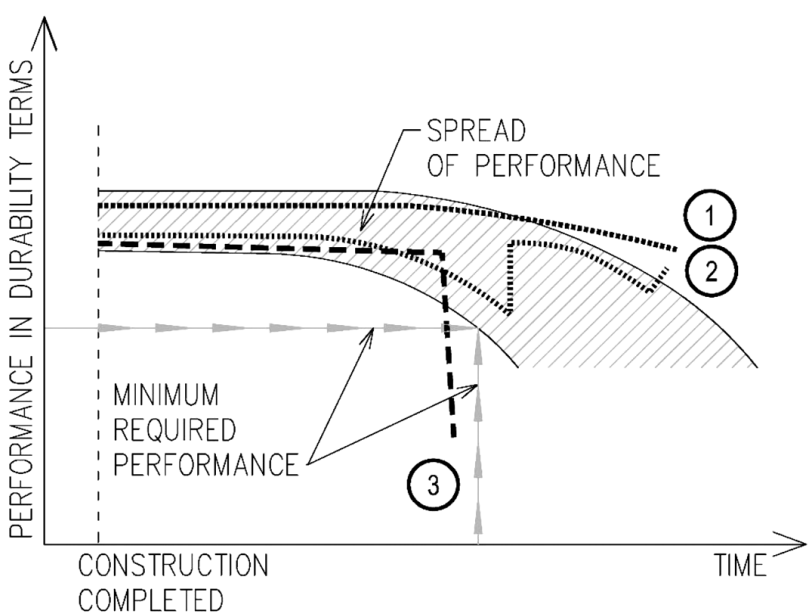

Figure 1: Loss of durability with time ${ }^{4}$

Slika 1: Zmanjšanje zdržljivosti s časom ${ }^{4}$

of the concrete cover can be considered as the measure of its durability. The thickness of the concrete cover can be defined as $40-60 \mathrm{~mm}$ from the surface of the structure. This layer can be the one covering the reinforcement in the case of a steel-reinforced structure.

Given that water is being constantly transported as a liquid and steam, the speed of its permeation into the inner structure of the concrete is dependent on the physical structure of the cement paste. There is a large number of mechanisms having a damaging effect on concrete and they can be described, e.g., by means of a holistic diagram presented in Figure 2. ${ }^{1}$

For a determination of concrete durability (the concrete-cover quality) numerous standardised and nonstandardised testing methods are used throughout Europe. These methods are mainly based on determining the permeability of the concrete-surface layer to those liquids and gasses that have substantial influences on the state of a reinforced concrete structure or a structural element.

Concrete-cover quality is closely connected with the internal structure and porosity of a material. Most of the commonly used methods are non-destructive or semidestructive and on their basis it is possible to define the quality of a concrete cover but it is not possible to precisely determine the internal structure of a concrete structure or a specimen as a whole. It was recently found that the use of computed tomography (CT) in the fields other than medicine is greatly beneficial. X-rays can be used for examining the specimens of virtually any material. Tomographic data enables us to display an internal structure at any level and, using appropriate software, to construct a 3D model of the object. The 3D model facilitates an easier visualisation of the distribution of detected defects within the shape of the object.

This paper describes in detail an experiment whose aim was to compare the results of the commonly used methods for determining the concrete-cover permeability to liquids and gasses (and thereon the dependent concrete durability) with the outcomes of a measurement performed with CT. The methodology and the advantages and disadvantages of the individual methods used are described in more detail in the following sections.

\section{POSSIBILITIES OF DETERMINING PERMEABILITY OF CONCRETE COVER}

One of the standardised methods for determining the permeability of the surface layer of concrete is the depth of penetration of water under pressure according to EN 12390-8. ${ }^{5}$ The test is performed with cube-, cylinder- or prism-shaped specimens. The specimens submerged under water are tested at the age of $28 \mathrm{~d}$ when they are placed in a water-permeability apparatus so that they are loaded perpendicularly to the direction of compaction the top face of a specimen is not tested. The specimens are exposed to water at a pressure of $(500 \pm 50) \mathrm{kPa}$ for $(72 \pm 2) \mathrm{h}$. The specimens are split during the tensile splitting-strength test in order to reveal the maximum depth of the water penetration.

For the determination of the water permeability of concrete cover, a GWT (Germann Water Permeation Test) device is used. It is produced by the Danish company Germann Instruments and works on the principle of measuring the flow of water through a given area. The concrete-cover-permeability value can be obtained from the set water pressure and the volume of hardened cement paste within the overall volume of concrete. The

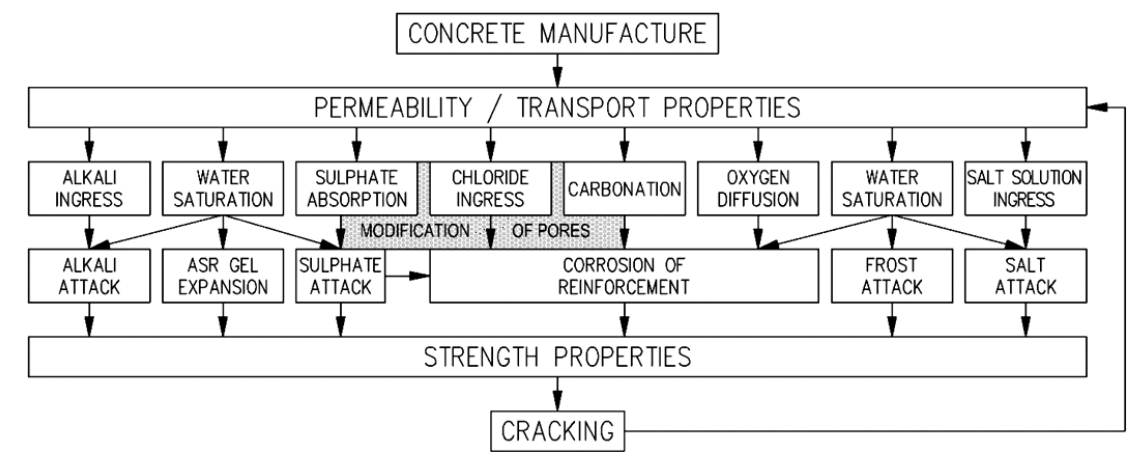

Figure 2: Causes of deterioration - physical-property interaction model Slika 2: Vzroki slabšanja - fizikalne lastnosti interakcijskega modela 
measurement is affected by the inlet and outlet water pressure, its dynamic viscosity, density and acceleration due to gravity. The GWT measurement is performed by fixing a pressure chamber fitted with a gasket with freshly applied silicone sealant, securing it onto the tested area with clamps and filling it with distilled water. After $5 \mathrm{~min}$ of wetting the concrete surface, the measuring itself is started. The chamber is pressurised to 0.2 bar. A micrometric gauge is used to determine the volume of the absorbed water and, simultaneously, the time is being measured. The measurement ends when the gauge is fully extended, i.e., to $20 \mathrm{~mm}^{6}$

The values of the initial surface permeability can also be obtained using the initial surface absorption test (ISAT). This method was developed in Italy as a method for measuring the state of the surface structure of concrete and it is specified in the British standard BS 1881-208:1996. ${ }^{7}$ It involves measuring the volume of water under pressure penetrating into a specimen through a given area. This area is defined by the area of an acrylic cap which is sealed onto the surface of a concrete composite.

The water volume is determined by measuring the flow rate of the water travelling through a capillary system of a known volume. A transparent reservoir is connected to the inlet and the cap's outlet is connected to a glass capillary. The capillary is fitted with a scale. Individual parts are connected with rubber tubes and the cap's inlet is fitted with a valve to regulate the water flow from the reservoir.

To achieve the necessary pressure of 0.02 bar, the capillary with the scale as well as the reservoir are placed $200 \mathrm{~mm}$ above the concrete surface. Upon filling the cap, the inlet is closed and the water-flow measurement starts. Readings are performed upon the first contact with water and then after $(10,30$ and 60) min. The number of scale units after the initial $5 \mathrm{~s}$ of the measurement determines the preliminary quality class of the concrete cover and also the period after which the data is recorded during the measurement: $30 \mathrm{~s}, 1 \mathrm{~min}$ or 2 min. $^{6}$ The obtained data is then compared with the classification table of concrete-cover water absorption based on the ISAT values (Table 1). ${ }^{8}$

Gas permeability of the concrete cover of a cement composite can be determined using a Torrent permeability tester (TPT) produced by the Swiss company Proceq. The principle of the test is the measurement of the air flow into the inner chamber of the device. A vacuum pump creates a vacuum of 1000 mbar, after which the pump is switched off and the air flow through the concrete into the inner chamber is observed. The device measures and calculates the permeability coefficient $k_{\mathrm{T}}$, the depth of penetration of the vacuum and the pressure after the pressure equalisation between the inner and the outer chamber of the vacuum cap. ${ }^{6}$ The method is specified in the Swiss standard SN 505 262/1. ${ }^{9}$ The moisture content of a specimen (structure) plays an important role in assessing concrete covers and for this reason a determination of the current moisture is also performed. ${ }^{10}$ The principle of the measurement using TPT lies in determining the quality of a tested surface according to Table 2. ${ }^{11}$

All the above mentioned methods are mostly performed in laboratories although the determination of water and air permeability using GWT, ISAT and TPT can also be carried out in situ.

Table 1: Classification of water absorption by concrete cover based on ISAT values $^{8}$

Tabela 1: Razporeditev absorpcije vode $\mathrm{v}$ površinski plasti betona $\mathrm{z}$ uporabo ISAT-vrednosti ${ }^{8}$

\begin{tabular}{|c|c|c|c|c|}
\hline \multirow{2}{*}{$\begin{array}{c}\text { Concrete } \\
\text { absorption }\end{array}$} & \multicolumn{4}{|c|}{ ISAT results $\left(\mathrm{mL} \mathrm{m}^{-2} \mathrm{~s}^{-1}\right)$} \\
\cline { 2 - 5 } & $10 \mathrm{~min}$ & $30 \mathrm{~min}$ & $60 \mathrm{~min}$ & $120 \mathrm{~min}$ \\
\cline { 2 - 5 } & $>0.5$ & $>0.35$ & $>0.2$ & $>0.15$ \\
\hline high & $0.25-0.5$ & $0.17-0.35$ & $0.10-0.20$ & $0.07-0.15$ \\
\hline medium & 0.25 time after starting the test \\
\hline low & $<0.25$ & $<0.17$ & $<0.10$ & $<0.07$ \\
\hline
\end{tabular}

Table 2: Classification of the quality of concrete cover based on TPT values ${ }^{11}$

Tabela 2: Razporeditev kvalitete površine betona $\mathrm{z}$ uporabo TPT-vrednosti ${ }^{11}$

\begin{tabular}{|c|c|c|}
\hline Quality of concrete cover & index & $k_{\mathrm{T}} /\left(10^{-16} \mathrm{~m}^{2}\right)$ \\
\hline very poor & 5 & $>10$ \\
\hline poor & 4 & $1.0-10$ \\
\hline medium & 3 & $0.1-1.0$ \\
\hline good & 2 & $0.01-0.1$ \\
\hline very good & 1 & $<0.01$ \\
\hline
\end{tabular}

\section{COMPUTED TOMOGRAPHY}

$\mathrm{X}$-ray computed tomography is a modern imaging method allowing a visualisation and analysis of objects. The advantage of this method is that it is a non-destructive method providing a display of the internal structure of a specimen in slices. The basic principle of the measurement using CT is shown in Figure 3. The specimen is secured onto a rotary stage between the $\mathrm{X}$-ray source and the detector array. The device records X-ray images at a certain angle while rotating the specimen by $360^{\circ}$. Tomographic reconstruction uses these X-ray scans to generate images representing the slices through the object (the so-called tomographic slices). Microtomography $(\mu \mathrm{CT})$ is the name for the tomography with a voxel resolution down to several micrometers, scanning internal structures of three-dimensional objects with a high spatial resolution. ${ }^{12,13}$

$\mu \mathrm{CT}$ finds use in a variety of fields where knowing the internal structure of a specimen of a heterogeneous material is a necessity for the evaluation of its properties and a comparison with the existing results.

The X-ray micro- and nanotomography laboratory established as a part of the Central European institute CEITEC has, at its disposal, a unique micrographic station GE Phoenix v|tome|x L 240 (with a voxel resolu- 


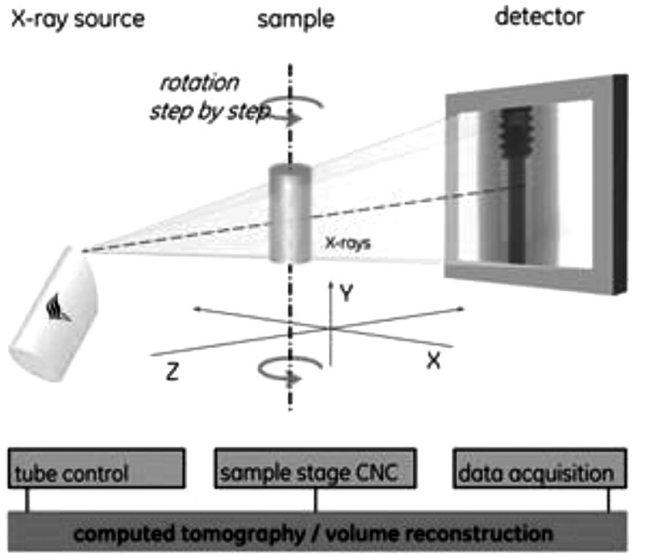

Figure 3: Diagram of the principle of scanning a specimen ${ }^{13}$ Slika 3: Prikaz principa skeniranja vzorca ${ }^{13}$

tion of up to $5 \mu \mathrm{m}$ for a $240 \mathrm{kV}$ microfocus X-ray tube) shown in Figure 4, which has been in use since September 2012. For the analysis of X-ray images, the VGStudio MAX software, equipped with a module for a pore analysis is used. ${ }^{14}$

For most European methods evaluating the pore structure of a concrete composite, the overall air content and microscopic air content are decisive for the so-called $A_{300}$ value, indicating the pores with a diameter of 0.3 $\mathrm{mm}(300 \mu \mathrm{m})$ and less. ${ }^{15}$ Among all the above-mentioned methods, only CT allows us to determine the $A_{300}$ value, the so-called effective air. ${ }^{16}$

\section{EXPERIMENT}

The described experiment is focused on a comparison of the evaluations of the concrete-cover quality achieved with the commonly applied methods (GWT, ISAT, TPT) and the findings obtained with CT. The main effort of the experiment is to ascertain whether CT provides a sufficient predictive value when evaluating the quality of a concrete cover in comparison with the above-mentioned methods.

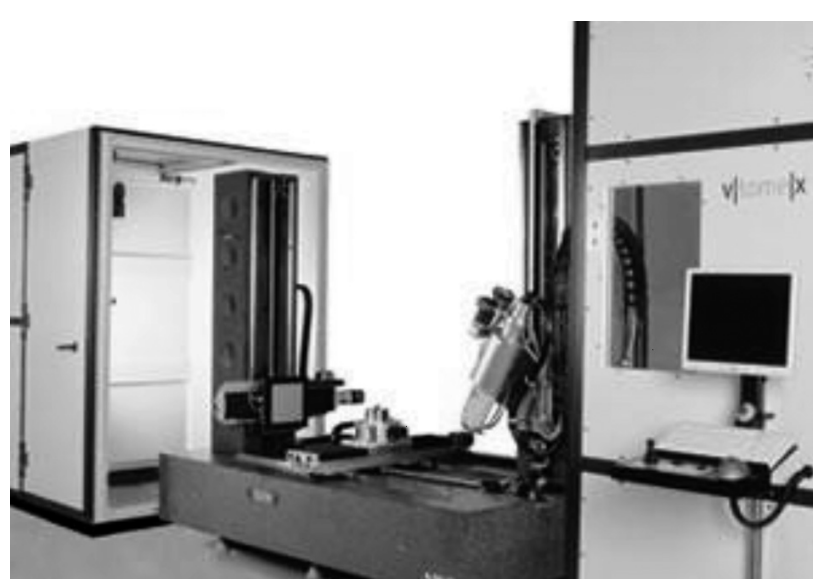

Figure 4: Microscope station GE Phoenix v|tome|x L $240^{16}$ Slika 4: Mikroskopska postaja GE Phoenix v|tome|x L $240^{16}$
Four different mixtures were chosen for the testing. They were always three-part concrete, i.e., made of concrete without any additives and admixtures in order to observe the changes in the internal structure of the concrete due to the changes in the cement proportion. The individual mixtures differed in the water/cement ratio depending on how much the portion of the cement was increased while maintaining consistency S3 according to EN 206. ${ }^{17}$ The mixture details are in Table 3. The components of the individual mixtures were identical, i.e., the same aggregates from the same locations, one type of cement from the same mill. Relevant properties of the components were checked against EN 196 ${ }^{18}$, EN $933^{19}$ and EN $1097^{20}$. Table 3 shows that the values of the water/cement ratio decrease depending on the amount of cement in the mixture, where the cement dosage was increased by approximately $50 \mathrm{~kg}$ in each consecutive mixture.

At the age of $28 \mathrm{~d}$ the following specimens were tested:

- for the depth of penetration of water under pressure, 12 cubes with a size of $150 \mathrm{~mm}$, designated with mixture-type codes R, 0/1, 0/2, 0/3 and numbers 1, 2, 3;

- using GWT, ISAT and TPT, a total of 12 specimens sized $300 \mathrm{~mm} \times 300 \mathrm{~mm} \times 150 \mathrm{~mm}$, designated with mixture-type codes $\mathrm{R}, 0 / 1,0 / 2,0 / 3$ and letters a, b, c;

- using the CT method, 4 samples were core drilled from the specimens used with the previous methods (GWT, ISAT and TPT); they were $50 \mathrm{~mm}$ in diameter and $60 \mathrm{~mm}$ in length; their dimensions were chosen on the basis of the requirement to check the surface layer of the concrete and the resolution settings of the software used.

Table 3: Compositions of the mixtures

Tabela 3: Sestava mešanic

\begin{tabular}{|c|c|c|c|c|c|c|}
\hline \multirow[b]{2}{*}{$\begin{array}{c}\text { Compo- } \\
\text { nent }\end{array}$} & \multicolumn{3}{|c|}{ Aggregates $(\mathrm{kg})$} & \multirow[b]{2}{*}{$\begin{array}{c}\text { Cement } \\
42.5 \mathrm{R} \\
(\mathrm{kg})\end{array}$} & \multirow[b]{2}{*}{$\begin{array}{c}\text { Water } \\
(\mathrm{kg})\end{array}$} & \multirow[b]{2}{*}{$\begin{array}{c}\text { Water/ } \\
\text { cement } \\
\text { ratio }\end{array}$} \\
\hline & $\mid \begin{array}{c}0-4 \\
\text { Bratčice }\end{array}$ & $\begin{array}{c}4-8 \\
\text { Olbramo- } \\
\text { vice }\end{array}$ & $\begin{array}{c}8-16 \\
\text { Olbramo- } \\
\text { vice }\end{array}$ & & & \\
\hline \multicolumn{7}{|c|}{ Concrete mixture $\mathrm{R}-\mathrm{C} 12 / 15$ X0 S3 D16 } \\
\hline $\begin{array}{l}\text { Concrete } \\
\text { mixture }\end{array}$ & 953 & 173 & 675 & 248 & 201 & 0.75 \\
\hline \multicolumn{7}{|c|}{ Concrete mixture 0/1 - C20/25 X0 S3 D16 } \\
\hline $\begin{array}{l}\text { Concrete } \\
\text { mixture }\end{array}$ & 925 & 182 & 696 & 308 & 203 & 0.61 \\
\hline \multicolumn{7}{|c|}{ Concrete mixture 0/2 - C30/37 X0 S3 D16 } \\
\hline $\begin{array}{l}\text { Concrete } \\
\text { mixture }\end{array}$ & 889 & 174 & 693 & 357 & 201 & 0.53 \\
\hline \multicolumn{7}{|c|}{ Concrete mixture $0 / 3-\mathrm{C} 35 / 45$ X0 S3 D16 } \\
\hline $\begin{array}{l}\text { Concrete } \\
\text { mixture }\end{array}$ & 826 & 195 & 669 & 392 & 208 & 0.50 \\
\hline
\end{tabular}

\section{RESULTS AND DISCUSSION}

Mixture R exhibits the highest permeability as indicated by the average value of the depth of penetration of water under pressure - up to three times more than the 
other mixtures. These results were expected for the given mixture design - its water/cement ratio was the highest (0.75) and it had the smallest amount of cement. Next, concretes $0 / 1$ and $0 / 2$ displayed lower values of the depth of penetration of water under pressure. Concrete mixture $0 / 3$ had the lowest average value of the depth of penetration of water under pressure, which proved the tendency of the maximum depth of penetration to decrease in dependence of the increase in the amount of cement in the mixture (Table 4 and Figure 5).

Table 4: Results of the depth of penetration of water under pressure Tabela 4: Rezultati globine penetracije vode pod tlakom

\begin{tabular}{|c|c|c|}
\hline Specimen & $\begin{array}{c}\text { Depth of } \\
\text { penetration }(\mathrm{mm})\end{array}$ & $\begin{array}{c}\text { Average value of } \\
\text { depth of penetration } \\
(\mathrm{mm})\end{array}$ \\
\hline $\mathrm{R}-1$ & 105 & 102 \\
\hline $\mathrm{R}-2$ & 90 & \\
\hline $\mathrm{R}-3$ & 110 & 34 \\
\hline $0 / 1-1$ & 30 & \\
\hline $0 / 1-2$ & 34 & \\
\hline $0 / 1-3$ & 38 & 35 \\
\hline $0 / 2-1$ & 38 & \\
\hline $0 / 2-2$ & 29 & \\
\hline $0 / 2-3$ & 37 & 24 \\
\hline $0 / 3-1$ & 31 & \\
\hline $0 / 3-2$ & 20 & \\
\hline $0 / 3-3$ & 22 & \\
\hline
\end{tabular}

The evaluation of the results of GWT, ISAT and TPT revealed that the specimens made from mixture $\mathrm{R}$ (the cement content of $248 \mathrm{~kg}$ ) had the lowest results for the water and air permeability. It is the mixture with the smallest portion of the cement and the highest water/ cement ratio of 0.75 .

Mixture 0/1 containing approximately $50 \mathrm{~kg}$ of cement more (the cement content of $308 \mathrm{~kg}$ ) with the water/cement ratio of 0.61 displayed lower values of the concrete-cover permeability compared to mixture $\mathrm{R}$. The

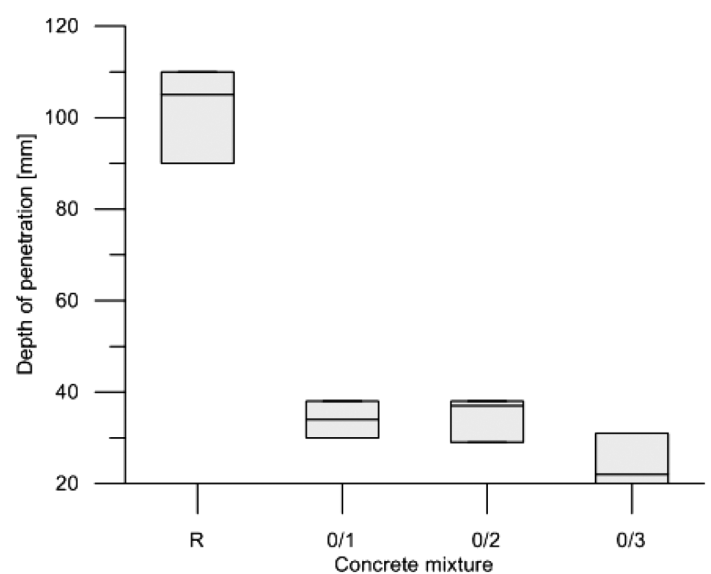

Figure 5: Dependence of average depth of penetration of water under pressure on mixture type

Slika 5: Odvisnost povprečne globine penetracije vode pod tlakom od vrste mešanice quality improvement was proved with all the methods used.

Mixture 0/2 showed a slight increase in the concrete-cover quality compared to mixture $0 / 1$. Mixture $0 / 2$ has a higher cement content, again by approximately $50 \mathrm{~kg}$ (the cement content of $357 \mathrm{~kg}$ ) compared to mixture $0 / 1$ and a lower water/cement ratio of 0.53 ; however, the obtained values do not differ as significantly as in the cases of mixtures $\mathrm{R}$ and $0 / 1$.

The last mixture, designated as $0 / 3$, with the highest portion of the cement (the cement content of $392 \mathrm{~kg}$ ) and the lowest water/cement ratio of 0.50 showed the best measurement results, reaching the values significantly lower than those for mixture $0 / 2$.

The measurement results obtained with the GWT, ISAT and TPT methods (Tables 5 to 7) show an apparent tendency where the quality parameters of the water and air permeability improve as the cement content in the mixtures is increased while maintaining the same amount of water. The obtained results were presented in tables and afterwards corresponding graphs were created (Figures 6 to 8). For a better result interpretation it is necessary to take into account the number of performed measurements where the following numbers of tests were performed for each method:

- GWT - 6 measurements (two measurements were performed on each of the three specimens a, b, c);

- ISAT - 6 measurements (two measurements were performed on each of the three specimens a, b, c);

Table 5: GWT results

Tabela 5: Rezultati GWT

\begin{tabular}{|c|c|c|}
\hline Specimen & $\begin{array}{l}\text { Permeability } \\
(\mathrm{mm} / \mathrm{s})\end{array}$ & $\begin{array}{c}\text { Total average value } \\
(\mathrm{mm} / \mathrm{s})\end{array}$ \\
\hline \multirow{2}{*}{$\mathrm{R}-\mathrm{a}$} & $2.89 \mathrm{E}-03$ & \multirow{6}{*}{$3.66 \mathrm{E}-03$} \\
\hline & $3.47 \mathrm{E}-03$ & \\
\hline \multirow{2}{*}{$\mathrm{R}-\mathrm{b}$} & $4.33 \mathrm{E}-03$ & \\
\hline & $4.33 \mathrm{E}-03$ & \\
\hline \multirow{2}{*}{$\mathrm{R}-\mathrm{c}$} & $3.47 \mathrm{E}-03$ & \\
\hline & $3.47 \mathrm{E}-03$ & \\
\hline \multirow{2}{*}{$0 / 1-a$} & $2.48 \mathrm{E}-03$ & \multirow{6}{*}{$1.90 \mathrm{E}-03$} \\
\hline & $1.58 \mathrm{E}-03$ & \\
\hline \multirow{2}{*}{$0 / 1-b$} & $1.93 \mathrm{E}-03$ & \\
\hline & $2.48 \mathrm{E}-03$ & \\
\hline \multirow{2}{*}{$0 / 1-c$} & $1.24 \mathrm{E}-03$ & \\
\hline & $1.73 \mathrm{E}-03$ & \\
\hline \multirow{2}{*}{$0 / 2-a$} & $2.48 \mathrm{E}-03$ & \multirow{6}{*}{$1.79 \mathrm{E}-03$} \\
\hline & $1.33 \mathrm{E}-03$ & \\
\hline \multirow{2}{*}{$0 / 2-b$} & $2.17 \mathrm{E} 03$ & \\
\hline & $1.58 \mathrm{E}--03$ & \\
\hline \multirow{2}{*}{$0 / 2-c$} & $1.93 \mathrm{E}-03$ & \\
\hline & $1.24 \mathrm{E}-03$ & \\
\hline \multirow{2}{*}{$0 / 3-a$} & $3.10 \mathrm{E}-04$ & \multirow{6}{*}{$4.91 \mathrm{E}-04$} \\
\hline & $5.78 \mathrm{E}-04$ & \\
\hline \multirow{2}{*}{$0 / 3-b$} & $4.81 \mathrm{E}-04$ & \\
\hline & $4.56 \mathrm{E}-04$ & \\
\hline \multirow{2}{*}{$0 / 3-c$} & $5.42 \mathrm{E}-04$ & \\
\hline & $5.78 \mathrm{E}-04$ & \\
\hline
\end{tabular}




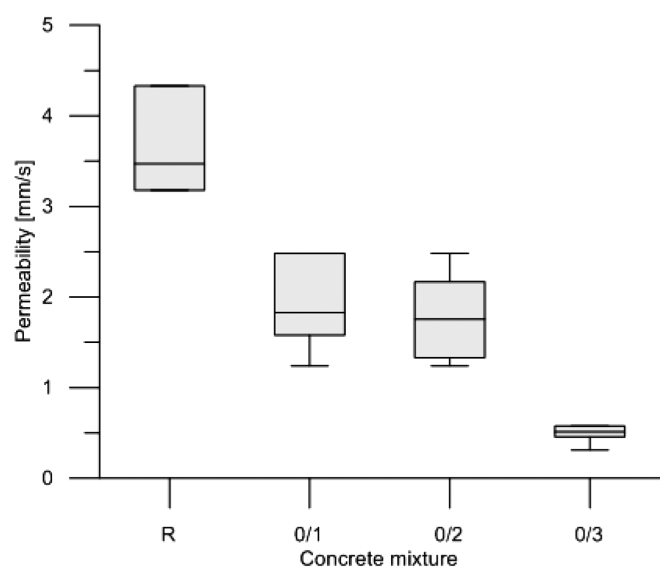

Figure 6: Dependency of permeability on mixture type using GWT Slika 6: Odvisnost prevodnosti od vrste mešanice, določene z GWT

- TPT - 9 measurements (three measurements were performed on each of the three specimens a, b, c).

Previous research revealed that the pores with a diameter of up to $300 \mu \mathrm{m}$ present in a concrete cover are very advantageous since their size does not allow the appearance or development of microcracks which later cause concrete-cover degradation. Therefore, it is desirable, especially for the surface of steel-reinforced concrete, that the largest proportion of the pores includes the

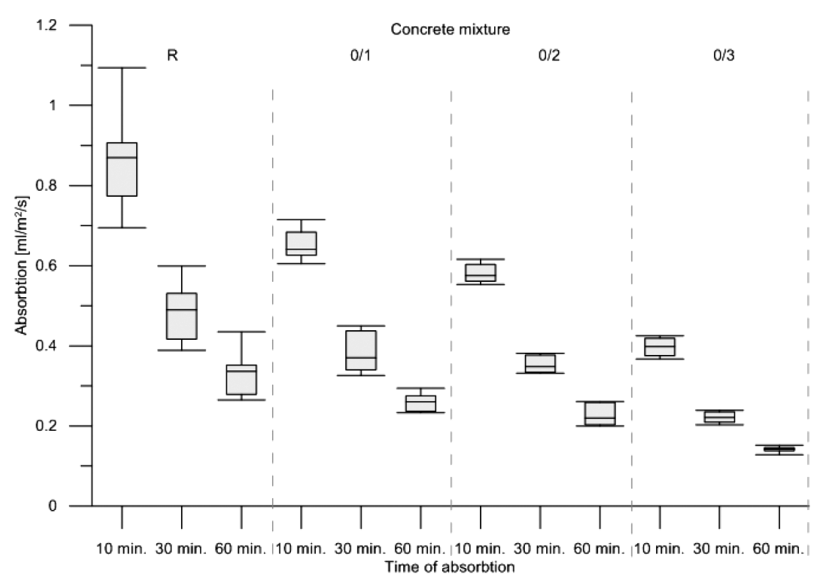

Figure 7: Dependency of permeability on mixture type using ISAT Slika 7: Odvisnost prepustnosti od vrste mešanice, določene z ISAT

ones of up to $300 \mu \mathrm{m}$. As far as this experiment is concerned, the information about the total air content and $A_{300}$ can be determined from the data obtained using only $\mu \mathrm{CT}$.

The requirements for the CT output data were the values of the total air content in the selected specimens and the volume of the pores of up to $300 \mu \mathrm{m}$ in diameter - value $A_{300}$. Given the resolution, the bottom threshold for the pore diameter was set to $100 \mu \mathrm{m}$. The obtained

Table 6: ISAT results

Tabela 6: Rezultati ISAT

\begin{tabular}{|c|c|c|c|c|c|c|c|c|c|}
\hline \multirow[t]{2}{*}{ Specimen } & \multicolumn{2}{|c|}{$\begin{array}{c}\text { Permeability } 10 \text { min after } \\
\text { the start of the test } \\
\left(\mathrm{mL} / \mathrm{m}^{2} / \mathrm{s}\right)\end{array}$} & \multirow{2}{*}{$\begin{array}{l}\text { Absorp- } \\
\text { tion of } \\
\text { concrete }\end{array}$} & \multicolumn{2}{|c|}{$\begin{array}{c}\text { Permeability } 30 \text { min after } \\
\text { the start of the test } \\
\left(\mathrm{mL} / \mathrm{m}^{2} / \mathrm{s}\right)\end{array}$} & \multirow{2}{*}{$\begin{array}{l}\text { Absorp- } \\
\text { tion of } \\
\text { concrete }\end{array}$} & \multicolumn{2}{|c|}{$\begin{array}{c}\text { Permeability } 60 \text { min after } \\
\text { the start of the test } \\
\left(\mathrm{mL} / \mathrm{m}^{2} / \mathrm{s}\right)\end{array}$} & \multirow{2}{*}{$\begin{array}{l}\text { Absorp- } \\
\text { tion of } \\
\text { concrete }\end{array}$} \\
\hline & $\begin{array}{c}\text { measured } \\
\text { value }\end{array}$ & $\begin{array}{l}\text { average } \\
\text { value }\end{array}$ & & $\begin{array}{c}\text { measured } \\
\text { value }\end{array}$ & $\begin{array}{l}\text { average } \\
\text { value }\end{array}$ & & $\begin{array}{c}\text { measured } \\
\text { value }\end{array}$ & $\begin{array}{l}\text { average } \\
\text { value }\end{array}$ & \\
\hline \multirow{2}{*}{$\mathrm{R}-\mathrm{a}$} & 0.695 & \multirow{6}{*}{0.868} & \multirow{6}{*}{ high } & 0.389 & \multirow{6}{*}{0.486} & \multirow{6}{*}{ high } & 0.265 & \multirow{6}{*}{0.334} & \multirow{6}{*}{ high } \\
\hline & 0.907 & & & 0.500 & & & 0.332 & & \\
\hline \multirow{2}{*}{$\mathrm{R}-\mathrm{b}$} & 1.094 & & & 0.599 & & & 0.435 & & \\
\hline & 0.846 & & & 0.480 & & & 0.340 & & \\
\hline \multirow{2}{*}{$\mathrm{R}-\mathrm{c}$} & 0.774 & & & 0.417 & & & 0.279 & & \\
\hline & 0.893 & & & 0.531 & & & 0.352 & & \\
\hline \multirow{2}{*}{$0 / 1-a$} & 0.684 & \multirow{6}{*}{0.652} & \multirow{6}{*}{ high } & 0.437 & \multirow{6}{*}{0.382} & \multirow{6}{*}{ high } & 0.275 & \multirow{6}{*}{0.259} & \multirow{6}{*}{ high } \\
\hline & 0.605 & & & 0.326 & & & 0.237 & & \\
\hline \multirow{2}{*}{$0 / 1-b$} & 0.642 & & & 0.375 & & & 0.271 & & \\
\hline & 0.626 & & & 0.340 & & & 0.233 & & \\
\hline \multirow{2}{*}{$0 / 1-c$} & 0.640 & & & 0.365 & & & 0.249 & & \\
\hline & 0.715 & & & 0.450 & & & 0.294 & & \\
\hline \multirow{2}{*}{$0 / 2-a$} & 0.560 & \multirow{6}{*}{0.580} & \multirow{6}{*}{ high } & 0.376 & \multirow{6}{*}{0.353} & \multirow{6}{*}{ high } & 0.259 & \multirow{6}{*}{0.227} & \\
\hline & 0.567 & & & 0.380 & & & 0.261 & & \\
\hline & 0.615 & & & 0.352 & & & 0.223 & & high \\
\hline $0 / 2-b$ & 0.603 & & & 0.344 & & & 0.200 & & high \\
\hline & 0.553 & & & 0.334 & & & 0.217 & & \\
\hline $0 / 2-c$ & 0.583 & & & 0.332 & & & 0.203 & & \\
\hline & 0.403 & & & 0.213 & & & 0.140 & & \\
\hline $0 / 3-a$ & 0.425 & & & 0.229 & & & 0.146 & & \\
\hline & 0.367 & & & 0.209 & & & 0.138 & & \\
\hline $0 / 3-b$ & 0.375 & 0.396 & medium & 0.203 & 0.221 & medium & 0.128 & 0.141 & medium \\
\hline & 0.419 & & & 0.235 & & & 0.144 & & \\
\hline $0 / 3-c$ & 0.393 & & & 0.239 & & & 0.152 & & \\
\hline
\end{tabular}


Table 7: TPT results

Tabela 7: Rezultati TPT

\begin{tabular}{|c|c|c|c|c|c|c|}
\hline \multirow[t]{2}{*}{ Specimen } & $\begin{array}{l}\text { Current mass } \\
\text { humidity }(\%)\end{array}$ & $\begin{array}{l}\text { Value of } k_{\mathrm{T}} \text { for } \\
\text { current humidity } \\
\left(10^{-16} \mathrm{~m}^{2}\right)\end{array}$ & $\begin{array}{l}\text { Value of } k_{\mathrm{T}} \text { for } \\
\text { current humidity } \\
\left(10^{-16} \mathrm{~m}^{2}\right)\end{array}$ & $\begin{array}{l}\text { Correction value of } \\
k_{\mathrm{T}} \text { for } w=3 \% \\
\left(10^{-16} \mathrm{~m}^{2}\right)\end{array}$ & $\begin{array}{c}\text { Correction value of } \\
k_{\mathrm{T}} \text { for } w=3 \% \\
\left(10^{-16} \mathrm{~m}^{2}\right)\end{array}$ & \multirow{2}{*}{$\begin{array}{c}\text { Quality of } \\
\text { concrete cover } \\
\text { for } w=3 \%\end{array}$} \\
\hline & average value & measured value & average value & average value & total average value & \\
\hline \multirow{3}{*}{$\mathrm{R}-\mathrm{a}$} & \multirow{3}{*}{3.72} & 1.587 & \multirow{3}{*}{1.634} & \multirow{3}{*}{1.896} & \multirow{9}{*}{1.577} & \multirow{9}{*}{ poor } \\
\hline & & 2.603 & & & & \\
\hline & & 0.712 & & & & \\
\hline \multirow{3}{*}{$\mathrm{R}-\mathrm{b}$} & \multirow{3}{*}{3.68} & 1.562 & \multirow{3}{*}{1.172} & \multirow{3}{*}{1.226} & & \\
\hline & & 1.583 & & & & \\
\hline & & 0.371 & & & & \\
\hline \multirow{3}{*}{$\mathrm{R}-\mathrm{c}$} & \multirow{3}{*}{3.75} & 2.185 & \multirow{3}{*}{1.437} & \multirow{3}{*}{1.610} & & \\
\hline & & 1.015 & & & & \\
\hline & & 1.110 & & & & \\
\hline \multirow{3}{*}{$0 / 1-a$} & \multirow{3}{*}{3.90} & 0.031 & \multirow{3}{*}{0.047} & \multirow{3}{*}{0.149} & \multirow{9}{*}{0.197} & \multirow{9}{*}{ medium } \\
\hline & & 0.047 & & & & \\
\hline & & 0.062 & & & & \\
\hline \multirow{3}{*}{$0 / 1-b$} & \multirow{3}{*}{4.10} & 0.041 & \multirow{3}{*}{0.041} & \multirow{3}{*}{0.179} & & \\
\hline & & 0.038 & & & & \\
\hline & & 0.044 & & & & \\
\hline \multirow{3}{*}{$0 / 1-c$} & & 0.072 & & & & \\
\hline & 4.20 & - & 0.067 & 0.262 & & \\
\hline & & 0.062 & & & & \\
\hline & & 0.038 & & & & \\
\hline $0 / 2-a$ & 4.00 & 0.027 & 0.030 & 0.130 & & \\
\hline & & 0.024 & & & & \\
\hline & & 0.052 & & & & \\
\hline $0 / 2-b$ & 3.90 & 0.031 & 0.052 & 0.159 & 0.151 & medium \\
\hline & & 0.073 & & & & \\
\hline & & 0.054 & & & & \\
\hline $0 / 2-c$ & 4.00 & 0.047 & 0.045 & 0.165 & & \\
\hline & & 0.033 & & & & \\
\hline & & 0.032 & & & & \\
\hline $0 / 3-a$ & 4.22 & 0.015 & 0.023 & 0.158 & & \\
\hline & & 0.021 & & & & \\
\hline & & 0.022 & & & & \\
\hline $0 / 3-b$ & 4.15 & 0.012 & 0.016 & 0.117 & 0.124 & medium \\
\hline & & 0.013 & & & & \\
\hline & & 0.014 & & & & \\
\hline $0 / 3-c$ & 4.05 & 0.021 & 0.015 & 0.097 & & \\
\hline & & 0.011 & & & & \\
\hline
\end{tabular}

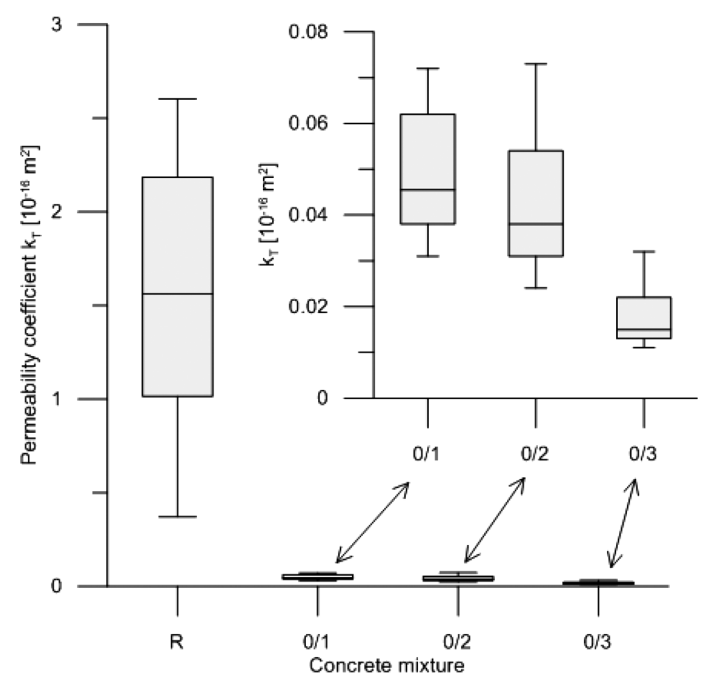

Figure 8: Dependency of permeability on mixture type using TPT Slika 8: Odvisnost prepustnosti od vrste mešanice, določene s TPT results are in Table 8. A great amount of the information was obtained mainly from 3D models (Figure 9), where, at the correct resolution settings, the pore distribution is clearly visible in the whole volumes of the specimens being scanned and only the pores of up to $300 \mu \mathrm{m}$ are indicated.

Only one sample with small dimensions, representing the whole mixture, was taken for CT scanning. For this reason, the test results may be distorted due to local defects.

Previous results ${ }^{21}$, where the effective-porosity value reached the average of $8 \%$, can be only partially compared with the results of this experiment. The reason for this is a different specimen size which determines the resolution settings of the scanner and the SW. Other factors influencing the evaluation of the experiment ${ }^{21}$ include a different technology of the concrete production and a different composition of the concrete. 
Table 8: CT results

Tabela 8: Rezultati CT

\begin{tabular}{|c|c|c|c|c|c|c|c|}
\hline $\begin{array}{l}\text { Concrete } \\
\text { mixture }\end{array}$ & Pore diameter & \begin{tabular}{|c|}
$\begin{array}{c}\text { Total volume of } \\
\text { the specimen } \\
\left(\mathrm{mm}^{3}\right)\end{array}$ \\
\end{tabular} & $\begin{array}{l}\text { Pore volume } \\
\qquad\left(\mathrm{mm}^{3}\right)\end{array}$ & $\begin{array}{l}\text { Pore content } \\
\qquad \%)\end{array}$ & $\begin{array}{c}\text { Ratio for } \\
\text { volume of pores } \\
<300 \mu \mathrm{m}(\%)\end{array}$ & $\begin{array}{l}\text { Pore surface } \\
\text { area }\left(\mathrm{mm}^{2}\right)\end{array}$ & $\begin{array}{c}\text { Ratio for pore } \\
\text { surface area < } \\
300 \mu \mathrm{m}(\%)\end{array}$ \\
\hline \multirow{2}{*}{$\mathrm{R}$} & all & \multirow{2}{*}{117388.26} & 2022.17 & 1.69 & \multirow{2}{*}{2.74} & 23218.03 & \multirow{2}{*}{14.86} \\
\hline & below $300 \mu \mathrm{m}$ & & 55.40 & 0.05 & & 3449.69 & \\
\hline \multirow{2}{*}{$0 / 1$} & all & \multirow{2}{*}{118220.09} & 2226.60 & 1.85 & \multirow{2}{*}{0.83} & 17407.05 & \multirow{2}{*}{6.02} \\
\hline & below $300 \mu \mathrm{m}$ & & 18.44 & 0.02 & & 1047.30 & \\
\hline \multirow{2}{*}{$0 / 2$} & all & \multirow{2}{*}{118296.94} & 2348.12 & 1.95 & \multirow{2}{*}{0.71} & 15689.52 & \multirow{2}{*}{6.14} \\
\hline & below $300 \mu \mathrm{m}$ & & 16.67 & 0.01 & & 962.59 & \\
\hline \multirow{2}{*}{$0 / 3$} & all & \multirow{2}{*}{123547.70} & 2136.65 & 1.70 & \multirow{2}{*}{0.86} & 19655.83 & \multirow{2}{*}{5.02} \\
\hline & below $300 \mu \mathrm{m}$ & & 18.46 & 0.01 & & 986.47 & \\
\hline
\end{tabular}

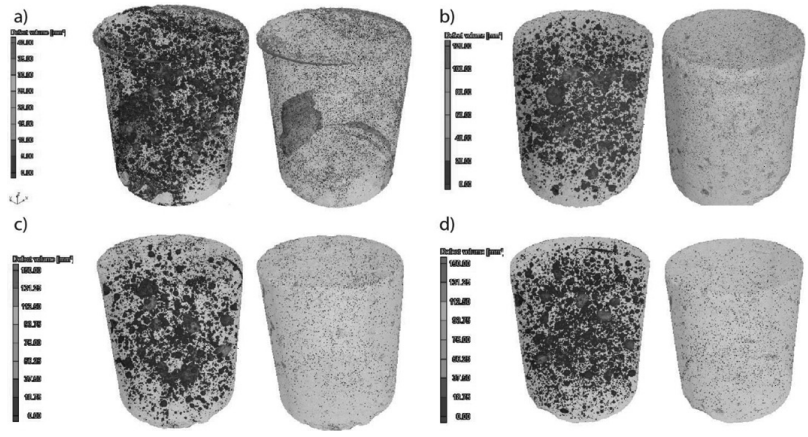

Figure 9: 3D models of mixture specimens: a) R, b) 0/1, c) $0 / 2$ and d) $0 / 3$, left total air content, right pores up to $300 \mu \mathrm{m}$

Slika 9: 3D-model vzorcev mešanic: a) R, b) $0 / 1$, c) $0 / 2$ in d) $0 / 3$, levo: celotna vsebnost zraka, desno: pore do $300 \mu \mathrm{m}$

\section{CONCLUSION}

The experimental results proved that:

- the standardised methods (the depth of penetration of water under pressure, GWT, ISAT and TPT) appear to be well applicable for assessing the concrete-cover permeability. During the comparison of the test results of the individual methods, a tendency was observed, according to which a decrease in the concrete-cover permeability (an improvement in the concrete durability) is dependent on the amount of cement in the individual concrete mixtures;

- the evaluation of the concrete-cover permeability using the standardised methods (the depth of penetration of water under pressure, GWT, ISAT and TPT) does not correspond with the data obtained from the 3D model created by CT;

- an advantage of CT is a possibility of monitoring the internal structure of a composite material and detecting flaws or defects. Not only the pores, their diameter and distribution also influence the permeability of the surface layer of concrete and so do capillaries and microcracks. However, the results obtained with CT are very sensitive to the resolution settings of the device - with respect to the required pore-diameter range, it is necessary to adapt the specimen size used in a $\mathrm{CT}$ measurement. In order to evaluate the experimental results with a greater precision, it is advisable to analyze a larger number of specimens from one sample of hardened concrete, which, given the financial requirements, is a subject for further experiments;

- on the basis of the measurement results obtained with CT, the method appears to be unsuitable for the evaluation of the permeability of the surface layer of concrete. The principle of the measurement using CT is useful for assessing concrete in other fields..$^{22-28}$

\section{Acknowledgement}

This paper was completed with the financial support of the Czech Science Foundation's project GA1318870S and European Union's "Operational Programme Research and Development for Innovations", No. CZ.1.05/2.1.00/03.0097, as an activity of the regional Centre AdMaS "Advanced Materials, Structures and Technologies".

\section{REFERENCES}

${ }^{1}$ A. E. Long, G. D. Henderson, F. R. Montgomery, Why assess the properties of near-surface concrete?, Construction and Building Materials, 15 (2001) 2-3, 65-79, doi:10.1016/S0950-0618(00) 00056-8

${ }^{2}$ B. Kucharczyková, Data for exercises of the subject BI03 - Diagnostic Methods in Civil Engineering, available from www.szk.fce.vutbr. cz/

${ }^{3}$ Regulation (EU) No 305/2011 of the European parliament, available from http://eur-lex.europa.eu/LexUriServ/LexUriServ.do?uri=OJ:L: 2011:088:0005:0043:EN:PDF

${ }^{4}$ G. Sommerville, The interdependence of research, durability and structural design, Proceedings of a Symposium on Design Life of Buildings, London, 1984, 233-250

${ }^{5}$ EN 12390-8 Testing hardened concrete - Part 8: Depth of penetration of water under pressure, ÚNMZ, 2001

${ }^{6}$ T. Vymazal, P. Bayer, P. Rovnaníková, Effect of water/cement ratio on permeability of surface layer of cement mortar for water and air, In: Construction Materials, Nitra 2013, 108-115

${ }^{7}$ BS 1881: Part 5, Methods of testing hardened concrete for other than strength, BSI, 1996

${ }^{8}$ R. Torrent, L. Fernandez Luco (Eds.), Non-Destructive Evaluation of the Penetrability and Thickness of the Concrete Cover: Stateof-the-Art Report of RILEM, RILEM Publications S.A.R.L., 2007, 246 


\section{T. KOMÁRKOVÁ et al.: APPLICATION OF COMPUTED TOMOGRAPHY IN COMPARISON WITH ...}

${ }^{9}$ SN 505 262/1 Construction en béton - Spécifications complémentaires, Annexe E: Perméabilité à l'airdans les structures, NS, 2003

${ }^{10}$ B. Kucharczyková, P. Misák, T. Vymazal, Determination and Evaluation of the Air Permeability Coefficient using Torrent Permeability Tester, Russian Journal of Nondestructive Testing, 46 (2010) 3, 226-233, doi:10.1134/S1061830910030113

${ }^{11}$ J. Adámek, V. Juránková, O. Michalko, Monitoring of Sealing Technology Quality of Concrete by Determination of its Water and Gas Permeability, Proceedings of the 6th international workshop Strengthening and seal rocks and building structures in the early $21 \mathrm{st}$ century, Ostrava, 2001, 218-223

${ }^{12}$ L. Hobst, P. Bílek, O. Anton, T. Zikmund, Monitoring of anomalous distribution of wires in the calibration samples of fiber concrete by computed tomography, Beton TKS, (2014) 3, 54-57

${ }^{13}$ http://blogs.sun.ac.za/ctscanner/introduction/

${ }^{14}$ T. Zikmund, M. Petrilak, J. Kaiser, X-ray computed tomography for casting analysis, defectoscopy and dimensional in spection, Proceedings of the Conference Testing and quality in construction, Brno, 2013, 429-438

${ }^{15}$ EN 480-11 - Admixtures for concrete, mortar and grout - Test methods - Part 11: Determination of air void characteristics in hardened, ÚNMZ, 2006

${ }^{16} \mathrm{https}: / / \mathrm{www}$. gemeasurement.com/

${ }^{17}$ EN 206 Concrete - Specification, performance, production and conformity, ÚNMZ, 2013

${ }^{18}$ EN 196-6 Methods of testing cement - Part 6: Determination of fineness, ÚNMZ, 2010

${ }^{19}$ EN 933 Tests for geometrical properties of aggregates, ÚNMZ, 2012

${ }^{20} \mathrm{EN} 1097$ Tests for mechanical and physical properties of aggregates, ÚNMZ, 2011

${ }^{21}$ É. Lublóy, L. G. Balázs, Potentials in use of X-ray computer tomography (CT) to study concrete, Beton TKS, (2013) 6, 43
${ }^{22} \mathrm{~K}$. Wan, Q. Xu, Local porosity distribution of cement paste characterized by X-ray micro-tomography, Science China Technological Sciences, 57 (2014) 5, 953-961, doi:10.1007/s11431-014-5513-5

${ }^{23}$ D. Fukuda, M. Maruyama, Y. Nara, D. Hayashi, H. Ogawa, K. Kaneko, Observation of fracture sealing in high-strength and ultra-low-permeability concrete by micro-focus X-ray CT and SEM/EDX, International Journal of Fracture, 188 (2014) 2, 159-171, doi:10.1007/s10704-014-9952-6

${ }^{24} \mathrm{~S}$. Erdem, X-ray computed tomography and fractal analysis for the evaluation of segregation resistance, strength response and accelerated corrosion behaviour of self-compacting lightweight concrete, Construction and Building Materials, 61 (2014) 30, 10-17, doi:10.1016/j.conbuildmat.2014.02.070

${ }^{25}$ T. Suzuki, H. Ogata, R. Takada, M. Aoki, M. Ohtsu, Use of acoustic emission and X-ray computed tomography for damage evaluation of freeze-thawed concrete, Construction and Building Materials, 24 (2010) 12, 2347-2352, doi:10.1016/j.conbuildmat.2010.05.005

${ }^{26}$ A. C. Bordelon, J. R. Roesler, Spatial distribution of synthetic fibers in concrete with X-ray computed tomography, Cement and Concrete Composites, 53 (2014), 35-43, doi:10.1016/j.cemconcomp. 2014.04.007

${ }^{27}$ D. Braz, P. E. S. Almeida, L. M. G. Motta, R. C. Barroso, R. T. Lopes, Study of the concrete overlay (whitetopping) in paving using computed tomographic system, Nuclear Instruments and Methods in Physics Research Section A: Accelerators, Spectrometers, Detectors and Associated Equipment, 579 (2007) 1, 510-513, doi:10.1016/ j.nima.2007.04.112

${ }^{28}$ E. Gallucci, K. Scrivener, A. Groso, M. Stampanoni, G. Margaritondo, 3D experimental investigation of the microstructure of cement pastes using synchrotron X-ray microtomography $(\mu \mathrm{CT})$, Cement and Concrete Research, 37 (2007) 3, 360-368, doi:10.1016/ j.cemconres.2006.10.012 